\title{
NEW DOGMA OF CHRISTIANS
}

\section{Sabar Nababan}

Lecturer, Electrical Engineering Department, Faculty of Engineering, University of Mataram, Nusa Tenggara Barat, Indonesia.

Email: nababan.sabar@gmail.com

\section{Cite this article:}

Sabar Nababan (2021), New Dogma of Christians. African Journal of Culture, History,

Religion and Traditions 4(1), 41-44. DOI:

10.52589/AJCHRT

LDRWS7U6.

\section{Manuscript History}

Received: 13 Aug 2021

Accepted: 13 Sept 2021

Published: 27 Sept 2021

Copyright $\odot 2020$ The Author(s). This is an Open Access article distributed under the terms of Creative Commons Attribution-NonCommercialNoDerivatives 4.0 International (CC BY-NC-ND 4.0), which permits anyone to share, use, reproduce and redistribute in any medium, provided the original author and source are credited.
ABSTRACT: The author has been able to talk to God since 2012. This paper contains the results of conversations between the author, God Jahowa, and God Jesus. Many of the new dogmas in this paper are not yet in the Bible.

KEYWORDS: New dogma, dogma about Trinity, Christian. 


\section{INTRODUCTION}

\section{Testimony}

The author has an ability to speak through long distance tract with God Jahowa. This gift is a sort of sixth indra of the author. This gift of the author was obtained in 2008, but it has been more intensive since 2012. This gift is real at any time until now.

The author feels happy to speak with God. What the author may ask are the most important things. The author also feels happy to be able to share their experience with the reader.

Many things have been authorized from God Jahowa about the Christian dogma. The following is the new dogma given by God Jahowa to the author. God Jahowa wants all churches/denominations in the world to have the same perception about the new dogma. This new dogma is not in the Bible.

\section{A. New Dogma about Trinity}

Many dogmas about the Trinity are adopted by various church denominations in the world. For example, all (100\%) believe that the Spirit of God Jahowa became the Spirit of the God Jesus. According to God Jahowa, the true new dogma is:

A.1. The comparison of the Spirit of God Jahowa and the Spirit of the God Jesus Christ is $80 \%: 20 \%$. The Spirit is $20 \%$ this is given to the Virgin Mary as he contains, and this Spirit develops until adulthood.

According to God Jahowa, the Spirit of $20 \%$ is $30 \mathrm{~cm}$ long; while according to Bunda Maria, the God Jesus, the baby is around $40 \mathrm{~cm}$ long. God Jahowa said that they (spirits and the body) will be equally long within one month.

So, if we asked about the number of Christian Gods. The answer is two, namely God Jahowa and God Jesus.

A.2. About the Holy Spirit - according to God Jahowa, the Holy Spirit is a collection of the holy Old Testament human spirits, which was formed after God Jesus rose. The number of them is 5200 spirits, but now it has increased to 10,000 spirits, and is still likely to increase some more. The Spirit of God Jahowa has been given to them as much as $10 \%$ as a binder.

\section{B. The Creator of the Sun and Planets in the Milky Way Galaxy}

In the writer's conversation with God Jahowa about the Milky Way galaxy consisting of Sun, Mercury, Venus, Earth, Mars, Jupiter, Saturn, Uranus, Neptune, and Pluto, he said that he created the galaxy.

According to God Jahowa, the Milky Way galaxy at first was not named, so it could not be included in the Bible. However, after being named by American astronauts, God Jahowa felt the need to declare it to the author to be conveyed to the people. 


\section{Baptism is the Most Liked by God Jahowa}

God Jahowa prefers splash baptism (SB) compared to diving baptism. This is because diving baptism (DB) has weaknesses. The weakness of the DB is that in general, it is carried out to the Christian when he is 10 years and above, except for new converts. So, if there is a child of the congregation under the age of 10 years that dies having not being baptized, the angel will have difficulty directing him to heaven because there has been no sign or stamp in the spirit of the child concerned.

However, after the throat baptism was discussed in the spirit world with the leaders of the charismatic and pentecostal churches (September 23, 2019; at night), they did not agree with changes in the DB becoming SB. But God Jahowa asked the author, "Is there an alternative?" So the author answers that the alternative that can be done is to do the DB for babies from the age of one. Furthermore, those who are one year and above in age that have not been baptized must be baptized entirely. For a one year old, DB can be done on the river, pool or sea.

\section{Fasting 16 Days Is Teen Fasting}

There is a fasting that Christians above 17 years old can observe, namely 16 days fasting. In this fast, do not eat but drink three glasses of water a day: one by $6 \mathrm{am}$, one by 12 noon, and one by $6 \mathrm{pm}$.

This fast is not mandatory and it is only taken once in a lifetime. If the fasting is not perfect (it doesn't work), then it can be repeated after 7 months. The goal of this fasting is to make the spirit of children more holy.

\section{E. Fasting 31 Days is the Savior's Fasting}

Fasting 31 days is the Savior's fast, i.e. not eating but drinking three glasses of clear water per day: one by 6 am, one by 12 noon and one by $6 \mathrm{pm}$.

After observing the Savior's fasting, there is no more desire to get married. So this fast is very suitable to be carried out by prospective pastors and Catholic nurses.

This fast is taken once in a lifetime. If the fasting is not perfect (it doesn't work), then it can be repeated after 7 months.

This fasting can be taken by those who want to become Christian God after death in the spirit world (in heaven). However, there is no guarantee of being God because it will still be evaluated by God Jahowa, for example about the number of his sins.

In opening fasting, they should eat papaya or rice porridge two spoons per minute until half full. 


\section{F. Kollekte.}

God Jesus said that the maximum collecting offering per week was $1 \%$ of the monthly income. So, the total kollekte per month is a maximum of $4 \%$ of the net salary per month.

\section{G. Tithe Becomes Fiveth}

God Jahowa said that the Tithe was too heavy; it was reduced to Fiveth which is $5 \%$ of the net salary per month.

\section{H. Holy Banquet (HB): How Many Times a Year?}

HB implementation varies in each of the church denominations. There are those who carry it out every Sunday, and some carry it out once a month. God Jesus told the author that it should be held only once a year, which is the day of the death of God Jesus. 